\title{
Hubungan Berat Badan Lahir, Panjang Badan Lahir dan Jenis Kelamin dengan Kejadian Stunting
}

Zuhrotul Eka Yulis Anggraeni, Hendra Kurniawan, Mohammad Yasin, Anis Dwi

Aisyah

Fakultas Ilmu Kesehatan Universitas Muhammadiyah Jember, Jl. Karimata No. 49

Kecamatan Sumbersari Kabupaten Jember, Jawa Timur

Email: zuhrotulekayulis@unmuhjember.ac.id

Diterima tanggal : 31 Maret 2020

Direvisi tanggal : 20 April 2020

Dipublikasikan tanggal : 11 Juni 2020

\begin{abstract}
Abstrak
Latar Belakang dan Tujuan: Stunting merupakan masalah balita yang saat ini terjadi di berbagai daerah. Terjadinya stunting pada balita sering kali tidak disadari, dan setelah dua tahun baru terlihat balita tersebut pendek. Masalah gizi yang kronis pada balita disebabkan oleh asupan gizi yang kurang dalam waktu yang cukup lama akibat orang tua atau keluarga tidak tahu atau belum sadar untuk memberikan makanan yang sesuai dengan kebutuhan gizi anak. Faktor penyebab dari beberapa penelitian diantaramya masalah BBLR, Gizi, infeksi dan lain lain. Penelitian ini memiliki tujuan menganalisis hubungan berat badan lahir, panjang badan lahir dan jenis kelamin pada balita stunting.

Metode: Desain penelitian korelasional, dengan populasi balita stunting yang berada diwilayah desa Suci jumlah 58 orang. Jumlah sampel pada penelitian ini 48 balita dengan teknik sampling simple random sampling.

Hasil: Sebagian besar responden berjenis kelamin perempuan $(54,2 \%)$, memiliki riwayat berat badal lahir normal $(91,7 \%)$, memiliki panjang badan lahir kurang dari $50(52 \%)$. Hasil analisis bivariat menunjukkan pada indikator berat badan lahir $\mathrm{P}=0.550$, panjang badan lahir $\mathrm{P}=0,744$ sedangkan pada jenis kelamin $\mathrm{P}=$ 0,299 denan demikian semua variable tidak memiliki hubungan yang signifikan terhadap kejadian stunting.

Simpulan: Variable yang tidak berhubungan dengan kondisi stunting balita bisa dikarenakan faktor lain yang lebih dominan misal pemenuhan ASI dan pemenuhan gizi anak pada 6 bulan kehidupan pertama, sehingga perlu penelitian lebih lanjut mengenai faktor ini.
\end{abstract}

Kata Kunci: Berat badan lahir; Panjang badan lahir; Stunting

Sitasi: Anggaraeni Z E, Kurniawan H, Yasin M \& Aisyah A D . (2020). Hubungan berat badan lahir, panjang badan lahir dan jenis kelamin dengan kejadian stunting. The Indonesian Journal of Health Science. 12(1), 51-56

Copyright: () 2020 Anggareni et al. This is an open-access article distributed under the terms of the Creative Commons Attribution License, which permits unrestricted use, distribution, and reproduction in any medium, provided the original author and source are credited.

Diterbitkan Oleh: Universitas Muhammadiyah Jember

ISSN (Print): 2087-5053

ISSN (Online): 2476-9614 


\begin{abstract}
Introduction: Stunting is a problem that currently occurs in various regions. The occurrence of stunting in toddlers is often not realized, and after two years the toddler is seen to be short. Chronic nutritional problems in toddlers are caused by insufficient nutritional intake for a long time as a result of parents or families not knowing or not being aware of providing food that is in accordance with the nutritional needs of the child. The causative factors of several studies include the problem of low birth weight, nutrition, infection and others. This study aims to analyze the relationship between birth weight, birth length and sex in stunting infants.
\end{abstract}

Method: Correlational study design, with a population of 58 stunting children in the village of Suci. The number of samples in this study was 48 toddlers with simple random sampling technique.

Results: Most of the respondents were female (54.2\%), had a history of normal birth weight (91.7\%), had a birth length of less than 50 (52\%). The results of bivariate analysis showed that the indicator of birth weight was $P=0.550$, body length at birth was $P=0.744$, while sex, it was $P=0.299$, it could be concluded that all variables had no significant relationship to the incidence of stunting.

Conclucion: Variable conditions that are not related to the stunting condition of under five could be due to other factors that are more dominant, such as the fulfillment of breast milk and the fulfillment of children's nutrition in the first 6 months of life.

Keywords: Birth length; Birth weight; Stunting

\section{PENDAHULUAN}

Balita stunting merupakan kondisi dimana balita menglami kegagalan tumbuh yang berdampak pada kurangnya tinggi badan badan balita. Faktor penyebab terjadinya stunting bermacam macam. Kejadian balita pendek (stunting) di Indonesia menempati urutanan ke-5 dunia. Sekitar 5 juta dari 12 juta balita $(38,6)$ di Indonesia memiliki tinggi badan di bawah rata-rata tinggi badan balita dunia, khusunya di Jawa Timur balita berusia 0-5 tahun sebanyak 24.000 balita, menyatakan bahwa $12 \%$ balita berpotensi mengalami kecenderungan sangat pendek dan $30 \%$ pendek dan kabupaten Jember berada peringkat ke-5 se Jawa Timur dengan setatus balita gizi kurang dan status gizi buruk sebanyak 20.658 (13,08\%).
Terjadinya stunting pada balita sering kali tidak disadari, dan setelah dua tahun baru terlihat balita tersebut pendek. Masalah gizi yang kronis pada balita disebabkan oleh asupan gizi yang kurang dalam waktu yang cukup lama akibat orang tua / keluarga tidak tahu atau belum sadar untuk memberikan makanan yang sesuai dengan kebutuhan gizi anaknya. Data Riskesdas tahun 2010 menunjukkan bahwa ada 21,5\% balita usia 2-4 tahun yang mengonsumsi energi di bawah kebutuhan minimal, dan $16 \%$ yang mengonsumsi protein di bawah kebutuhan minimal. Bila hal ini berlangsung dalam waktu lama, maka akan mengganggu pertumbuhan berat dan btinggi badan Balita. Pada ibu hamil juga 
terdapat $44,4 \%$ yang mengonsumsi energi di bawah kebutuhan minimal dan $49,5 \%$ wanita hamil yang mengonsumsi protein di bawah kebutuhan minimal yang berdampak pada terhambatnya pertumbuhan janin yang dikandungnya (Kementerian Kesehatan RI, 2010).

Banyak factor penyebab terjadi stunting salah satunya adalah berat badan lahir rendah. Beberapa penelitan menyebutkan bawasanya anak dengan berat badan lahir rendah akan lebih beresiko terjadi stunting dari pada bayi yang lahir dengan kondisi normal.

\section{METODE PENELITIAN}

Desain penelitian yang digunakan adalah korelasional. Populasi pada penelitian ini adalah balita stunting sebanyak 58 balita. Jumlah sampel 48 balita teknik sampling yang digunakan adalah Simple random sampling. Data yang digunakan dalam penelitian ini adalah data sekunder berupa kohot balita

\section{HASIL}

\section{Karakteristik responden}

Tabel 1 menunjukkan bahwa sebagian besar responden berjenis kelamin perempuan yaitu sebanyak 26 responden $(54,2 \%)$, riwayat berat badan lahir normal sejumlah 44 responden $(91,7 \%)$, dan memiliki panjang badan lahir $<50 \mathrm{~cm}$ yaitu sebanyak 25 responden (52\%).

\section{Kejadian stunting}

Seperti terlihat pada tabel 2 diketahui bahwa seluruh responden $(100 \%)$ tidak mengalami stunting.

\section{Faktor stunting}

Berdasarkan tabel 3 diketahui dari hasil uji korelasi peason menunjukan $p$ value pada indikator berat badan lahir $0,550>0.05$, indikator tinggi badan lahir $p$ value $0,744>0,05$, sedangkan pada indikator jenis kelamin $p$ value $0,299>0,05$ sehingga dapat disimpulkan bahwa tidak ada hubungan antara berat badan lahir, tinggi badan lahir dan jenis kelamin dengan kejadian stunting pada balita.

Tabel 1. Karakteristik responden

\begin{tabular}{lcc}
\hline Karakteristik & Jumlah & Persentase (\%) \\
\hline Jenis kelamin & & \\
$\quad$ Laki laki & 22 & 45,9 \\
$\quad$ Perempuan & 26 & 54,1 \\
Riwayat berat badan lahir & & \\
$\quad$ BBLR & 4 & 8,3 \\
$\quad$ Normal & 44 & 91,7 \\
Riwayat panjang badan lahir & & \\
$\quad<50 \mathrm{~cm}$ & 25 & 52 \\
$=50 \mathrm{~cm}$ & 15 & 31 \\
$>50 \mathrm{~cm}$ & 8 & 17 \\
\hline
\end{tabular}

Tabel 2. Balita stunting

\begin{tabular}{lcc}
\hline Status Stunting & Jumlah & Persentase (\%) \\
\hline Stunting & 48 & 100 \\
Tidak stunting & 0 & 0 \\
\hline
\end{tabular}


Tabel 3. Hubungan antar varabel

\begin{tabular}{cccc}
\hline Indikator & Pearson Corelation & P Value & N \\
\hline BBL &,- 088 & 0,550 & 48 \\
PBL & 0,048 & 0,744 & 48 \\
Jenis Kelamin & 0,153 & 0,299 & 48 \\
\hline
\end{tabular}

\section{PEMBAHASAN}

Berat badan lahir pada bayi merupakan indicator yang dapat dipergunakan sebagai acuhan untuk dalam penentuan status apakah balita tersebut mengalami berat badan lahir rendah sesuai dengan indicator yang telah ditetab kan oleh WHO. Berdasarkan hasil penelitian disebutkan $\mathrm{P}$ value pada indicator berat badan lahir lebih dari 0,05 yaitu 0,550 dapat disimpulkan bahwa tidak ada hubungan antara berat badan lahir dengan kejadian stunting. Hal ini banyak bertententangan dengan penelitian penelitian terdahulu yaitu penelitian di Nepal (Paudel et al., 2012) menunjukkan bahwa berat badan lahir yang rendah memiliki risiko stunting 4,47 kali lebih besar daripada balita dengan berat lahir normal. Berat badan lahir merupakan salah satu indicator kesehatan pada bayi yang baru lahir. Berat badan lahir merupakan parameter yang sering dipakai untuk menggambarkan pertumbuhan janin pada masa kehamilan. Bayi dengan berat badan lahir rendah akan lebih rentan terhadap pengaruh lingkungan yang kurang baik di masa mendatang (Umboh, 2013).

Selama masa petumbuhan
anak banyak hal lain yang berpengaruh selain dari Berat badan lahir salah satunya adalah masalah gizi anak, kondisi kesehatan anak pada awal kehidupan. Kondisi ini sejalan dengan beberapa penelitian yang dilakukan oleh Berat lahir pada hasil penelitian ini tidak menunjukkan hubungan dengan kejadian stunting pada balita dapat disebabkan oleh banyak factor yang lebih besar pengaruhnya dengan kejadian stunting balita seperti ketidakcukupan gizi serta infeksi Selain itu efek berat badan lahir terhadap pertumbuhan tinggi badan paling besar terdapat pada usia 6 bulan pertama. Jika pada 6 bulan pertama balita dapat memperbaiki status gizinya, maka terdapat kemungkinan bahwa tinggi badan balita dapat tumbuh dengan normal dan terhindar dari kejadian stunting di usia selanjutnya (Adair dan Guilkey, 1997).

Tinggi badan lahir atau lebih dikenal dengan istilah Panjang badan balita memiliki nilai normal $50 \mathrm{~cm}$. Ada beberapa penelitian menyebutkan bahwa panjang badan lahir memiliki hubungan dengan kejadian panjang badan lahir. Baduta dengan panjang badan lahir rendah mempunyai risiko 6,29 kali lebih besar untuk menjadi stunting daripada baduta dengan panjang badan lahir normal. Pada penelitian hal ini menunjukan tidak ada hubungan antara panjang badan balita dengan kejadian stunting. Hal ini bias disebabkan factor lain seperti masukan gizi anak selama pengasuhan sehingga meskipun panjang badan anak pendek tetepi jika gizi anak terpenuhi dengan baik maka kejadian stunting tidak terjadi (Wellina, Kartasurya and Rahfiludin, 2016).

Jenis kelamin merupakan identitas pada balita. Berdasarkan 
hasil pengukuran jenis kelamin memiliki nilai $\mathrm{P}$ value lebih dari 0,05 yaitu 0,299 hal ini menunjukakan tidak ada hubungan antara jenis kelamin dengan kejadian stunting. Stunting 6-24 bulan berjenis kelamin laki-laki tidak berbeda jauh dibandingkan dengan perempuan yaitu $17,40 \%$ dan $19,80 \%$. Hasil statistic menunjukkan bahwa tidak ada hubungan jenis kelamin dengan stunting $\quad(\mathrm{p}<0,05) \quad$ (Rukmana, Briawan and Ekayanti, 2016). Hasil penelitian ini sama dengan hasil penelitian di Indonesia tahun 2013 prevalensi stunting tidak berbeda dengan anak laki-laki dibandingkan dengan perempuan dengan usia 0-23 bulan (Hayati 2013). Jenis kelamin baik anak perempuan dan laki-laki berisiko untuk menjadi stunting. Jenis kelamin juga tidak dibedakan dalam menentukan kebutuhan energi dan zat gizi anak 0-23 bulan (Mahan $\mathrm{K}$, \&Escott-Stump, 2008). Jenis kelamin hanya merupakan identitas dalam karakteristik sampel

\section{SIMPULAN}

Hasil penelitian ini menyimpulkan bahwa tidak ada hubungan yang signifikan antara berat badan lahir, panjang badan lahir, dan jenis kelamin baltia dengan kejadian stunting

\section{SARAN}

Bagi responden disarankan dapat memenuhi kebutuhan nutrisi yang optimal terutama pemberian ASI ekslusif dan pemeberian MP ASI berkualitas akan membantu mencegah kejadian stunting pada balita. Sedangkan bagi petugas kesehatan disarankan agar gencar memberikan penyuluhan terkait ASI ekslusif dan MPASI pada kader posyandu maupun pada ibu balita untuk mencegah stunting

\section{DAFTAR PUSTAKA}

Adair, L. S., \& Guilkey, D. K. (1997). Age specifi c determinant of stunting in Filipino children. The Journal of Nutrition, 127, 314-320. Diakses dari The Journal of Nutrition database

Aridiyah, Rohmawatu \& Ririanty (2015). Faktor-faktor yang mempengaruhi kejadian stunting pada anak balita di wilayah pedesaan dan perkotaan. Jurnal Pustaka Kesehatan. Vol.3. No.1. 47

Hayati AW. Faktor-Faktor Risiko Stunting, Pola Konsumsi Pangan, Asupan Energi dan Zat Gizi Anak 0-23 Bulan [Tesis]. Bogor: Ins- tititut Pertanian Bogor; 2013.

Kemenkes. (2010). Keputusan Menteri Kesehatan RI tentang Standar Antropometri Penilaian Status Gizi Anak. Jakarta: Kementerian Kesehatan RI.

Kemenkes. (2019). Angka kecukupan gizi yang dianjurkan untuk masyarakat indonesia. Jakarta: Kementerian Kesehatan RI.

Kusharisupeni. (2002). Peran status kelahiran terhadap stunting pada bayi: Sebuah studi prospektif. Jurnal Kedokteran Trisakti, 23(3), 73-80. Diakses dari http://www.univmed.org/ wp-

content/uploads/2011/02Kusha risupeni.Pdf

Kusuma, K. E. (2013). Faktor resiko kejadian stunting pada anak 
usia 2-3 tahun (Studi di Kecamatan Semarang Timur). Semarang: Universitas Diponegoro

Lestari, W, Ani, M, \& Zen, R. (2014). Faktor risiko stunting pada anak umur 6-24 bulan di kecamatan Penanggalan kota Subulussalam provinsi Aceh. Jurnal Gizi Indonesia, Volume 3, Nomor 1 .

Mahan K, \&Escott-Stump. Food, Nutrition, and Diet Therapy. USA: W.B. Saunders Company; 2008.

Nabuasa, C. D., Juffrie, \& Huriyati, E. (2013). riwayat pola asuh, pola makan, asupan zat gizi berhubungan dengan terhadap kejadian stunting pada anak usia 24-59 bulan di Kecamatan Biboki Utara Kabupaten Timor Tengah Utara Provinsi Nusa Tenggara Timur. Jurnal Gizi dan Dietetik Indonesia, Volume 1, Nomor 3.

Paudel, R. et al. (2012). Risk factors for stunting among children: A community based case control study in Nepal', Kathmandu University Medical Journal, 10(3).

Rukmana, E., Briawan, D. and Ekayanti, I. (2016). Faktor risiko stunting pada anak usia 6-24 bulan di Kota Bogor. Media Kesehatan Masyarakat Indonesia Universitas Hasanuddin, 12(3), pp. 192199.

Sulistyoningsih, Hariyani. (2011). Gizi untuk kesehatan ibu dan anak. Yogyakarta: Graha Ilmu.

Swathma D, Lestari, H \& Ardiansyah, R, T. (2016). Analisis Faktor Risiko BBLR, Panjang Badan Bayi Saat Lahir dan Riwayat Imunisasi Dasar
Terhadap Kejadian Stunting pada Balita Usia 12-36 Bulan Di Wilayah Kerja Puskesmas Kandai Kota Ken-dari Tahun 2016. Jurnal Ilmiah Mahasiswa Kesehatan Masyarakat, 1(3), hal.1-10.

Wellina, W. F., Kartasurya, M. I. and Rahfiludin, M. Z. (2016). Faktor risiko stunting pada anak umur 12-24 bulan', Jurnal Gizi Indonesia (The Indonesian Journal of Nutrition), 5(1), pp. 55-61. doi: 10.14710/jgi.5.1.55-61.

Umboh, A. (2013). Berat lahir rendah dan tekanan darah pada anak. Jakarta: Sagung Seto.

Utama, sp.FK \& HerqutantoMPH, MARS. (2015). Penuntun Diet Anak (hlm. 25- 26). Jakarta: Fakultas Kedokteran Universitas Indonesia 